University of Nebraska - Lincoln

DigitalCommons@University of Nebraska - Lincoln

Publications from USDA-ARS / UNL Faculty

U.S. Department of Agriculture: Agricultural

Research Service, Lincoln, Nebraska

2015

Midwest vision for sustainable fuel production

\author{
Kenneth J. Moore \\ lowa State University, kjmoore@iastate.edu \\ Stuart Birrell \\ lowa State University \\ Robert C. Brown \\ lowa State University \\ Michael D. Casler \\ USDA-ARS, michael.casler@ars.usda.gov \\ Jill E. Euken \\ lowa State University \\ See next page for additional authors
}

Follow this and additional works at: https://digitalcommons.unl.edu/usdaarsfacpub

Moore, Kenneth J.; Birrell, Stuart; Brown, Robert C.; Casler, Michael D.; Euken, Jill E.; Hanna, H. Mark; Hayes, Dermot J.; Hill, Jason D.; Jacobs, Keri L.; Kling, Cathy L.; Laird, David; Mitchell, Robert B.; Murphy, Patrick T.; Raj Raman, D.; Schwab, Charles V.; Shinners, Kevin J.; Vogel, Kenneth P.; and Volenec, Jeffrey J., "Midwest vision for sustainable fuel production" (2015). Publications from USDA-ARS / UNL Faculty. 1972.

https://digitalcommons.unl.edu/usdaarsfacpub/1972

This Article is brought to you for free and open access by the U.S. Department of Agriculture: Agricultural Research Service, Lincoln, Nebraska at DigitalCommons@University of Nebraska - Lincoln. It has been accepted for inclusion in Publications from USDA-ARS / UNL Faculty by an authorized administrator of DigitalCommons@University of Nebraska - Lincoln. 


\section{Authors}

Kenneth J. Moore, Stuart Birrell, Robert C. Brown, Michael D. Casler, Jill E. Euken, H. Mark Hanna, Dermot J. Hayes, Jason D. Hill, Keri L. Jacobs, Cathy L. Kling, David Laird, Robert B. Mitchell, Patrick T. Murphy, D. Raj Raman, Charles V. Schwab, Kevin J. Shinners, Kenneth P. Vogel, and Jeffrey J. Volenec 
This article was downloaded by: [76.84.244.77]

On: 08 September 2015, At: 21:15

Publisher: Taylor \& Francis

Informa Ltd Registered in England and Wales Registered Number: 1072954 Registered office: 5 Howick

Place, London, SW1P IWG

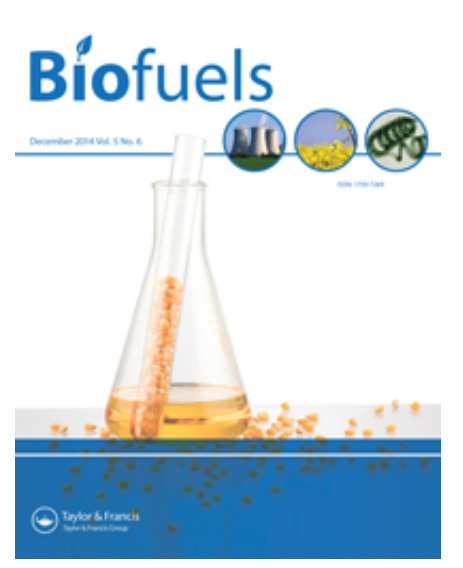

CrossMark

Click for updates

\section{Biofuels}

Publication details, including instructions for authors and subscription information: http:// www. tandfonline.com/loi/tbfu20

\section{Midwest vision for sustainable fuel production}

\author{
Kenneth J. Moore ${ }^{a}$, Stuart Birrell ${ }^{b}$, Robert C. Brown ${ }^{c}$, Michael D. Casler $^{d}$, Jill E. Euken ${ }^{c}$, \\ H. Mark Hanna ${ }^{b}$, Dermot J. Hayes ${ }^{c}$, J ason D. Hill ${ }^{\mathrm{e}}$, Keri L. Jacobs ${ }^{c}$, Cathy L. Kling ${ }^{c}$, David \\ Laird $^{c}$, Robert B. Mitchell ${ }^{d}$, Patrick T. Murphy ${ }^{f}$, D. Raj Raman ${ }^{b}$, Charles V. Schwab ${ }^{c}$, Kevin \\ J. Shinners ${ }^{g}$, Kenneth P. Vogel ${ }^{\mathrm{h}} \&$ J effrey J. Volenec ${ }^{\mathrm{i}}$ \\ ${ }^{a}$ Agronomy Department, lowa State University, Ames, IA, USA. \\ ${ }^{\mathrm{b}} \mathrm{Ag} \&$ Biosystems Engineering, lowa State University, Ames, IA, USA. \\ ${ }^{c}$ Bioeconomy Institute, lowa State University, Ames, IA, USA. \\ ${ }^{\mathrm{d}}$ USDA-ARS, Madison, WI, USA. \\ ${ }^{\mathrm{e}}$ Department of Bioproducts and Biosystems Engineering, University of Minnesota St \\ Paul, MN, USA. \\ ${ }^{f}$ Department of Agricultural and Biological Engineering, Purdue University, West \\ Lafayette, IN, USA. \\ ${ }^{9}$ Biological Systems Engineering, College of Agricultural and Life Sciences, University of \\ Wisconsin, Madison, WI, USA. \\ ${ }^{\mathrm{h}}$ USDA-ARS, Lincoln, NE, USA. \\ Agronomy department, Purdue University, West Lafayette, IN, USA. \\ Published online: 27 Mar 2015.
}

To cite this article: Kenneth J. Moore, Stuart Birrell, Robert C. Brown, Michael D. Casler, Jill E. Euken, H. Mark Hanna, Dermot J. Hayes, Jason D. Hill, Keri L. Jacobs, Cathy L. Kling, David Laird, Robert B. Mitchell, Patrick T. Murphy, D. Raj Raman, Charles V. Schwab, Kevin J. Shinners, Kenneth P. Vogel \& J effrey J. Volenec (2014) Midwest vision for sustainable fuel production, Biofuels, 5:6, 687-702, DOI: 10.1080/ 17597269.2015.1015312

To link to this article: http:// dx. doi.org/ 10.1080/ 17597269.2015. 1015312

\section{PLEASE SCROLL DOWN FOR ARTICLE}

Taylor \& Francis makes every effort to ensure the accuracy of all the information (the "Content") contained in the publications on our platform. However, Taylor \& Francis, our agents, and our licensors make no representations or warranties whatsoever as to the accuracy, completeness, or suitability for any purpose of the Content. Any opinions and views expressed in this publication are the opinions and views of the authors, and are not the views of or endorsed by Taylor \& Francis. The accuracy of the Content should not be relied upon and should be independently verified with primary sources of information. Taylor and Francis shall not be liable for any losses, actions, claims, proceedings, demands, costs, expenses, damages, and other liabilities whatsoever or howsoever caused arising directly or indirectly in connection with, in relation to or arising out of the use of the Content.

This article may be used for research, teaching, and private study purposes. Any substantial or systematic reproduction, redistribution, reselling, loan, sub-licensing, systematic supply, or distribution in any form to anyone is expressly forbidden. Terms \& Conditions of access and use can be found at http:// www.tandfonline.com/page/terms-and-conditions 


\title{
Midwest vision for sustainable fuel production
}

\begin{abstract}
Kenneth J. Moore ${ }^{1 *}$, Stuart Birrell ${ }^{2}$, Robert C. Brown ${ }^{3}$, Michael D. Casler ${ }^{5}$, Jill E. Euken ${ }^{3}$, H. Mark Hanna $^{2}$, Dermot J. Hayes ${ }^{4}$, Jason D. Hill ${ }^{6}$, Keri L. Jacobs', Cathy L. Kling ${ }^{4}$, David Laird', Robert B. Mitchell, Patrick T. Murphy ${ }^{3}$, D. Raj Raman ${ }^{2}$, Charles V. Schwab ${ }^{2}$, Kevin J. Shinners', Kenneth P. Vogel $^{8} \&$ Jeffrey J. Volenec ${ }^{9}$

This article charts the progress of CenUSA Bioenergy, a USDA-NIFA-AFRI coordinated agricultural project focused on the North Central region of the US. CenUSA's vision is to develop a regional system for producing fuels and other products from perennial grass crops grown on marginally productive land or land that is otherwise unsuitable for annual cropping. This article focuses on contributions CenUSA has made to nine primary systems needed to make this vision a reality: feedstock improvement; feedstock production on marginal land; feedstock logistics; modeling system performance; feedstock conversion into biofuels and other products; marketing; health and safety; education; and outreach. The final section, Future Perspectives, sets forth a roadmap of additional research, technology development and education required to realize commercialization.
\end{abstract}

Headquartered at Iowa State University, CenUSA Bioenergy (www.cenusa.iastate.edu/), a USDA-NIFAAFRI-coordinated agricultural project, was funded in 2011 to address the challenge of producing biofuels and other products in an environmentally sustainable manner that does not interfere with food production or cause adverse changes in land use. Perennial prairie grasses, including switchgrass, big bluestem and indiangrass, offer attractive alternatives to using food crops for bioenergy production.

The premise is that strategically placing perennial energy crops on land that is marginal or unsuitable for grain production will improve ecosystem services and improve the sustainability of agriculture in the region. This is because predominant cropping systems throughout much of the Central US rely on just a few crop species, generally corn and soybean, grown either continuously or in simple rotations. Most crops that are grown are supported by federal programs that encourage their production. These incentives have encouraged expansion of row crop production on land that is marginally productive economically and land that is not environmentally suitable for various reasons. Most of the latter is highly erosive and requires significant conservation measures to prevent high levels of soil erosion and consequent degradation of soil and water

\footnotetext{
Agronomy Department, lowa State University, Ames, IA, USA

${ }^{2} \mathrm{Ag} \&$ Biosystems Engineering, lowa State University, Ames, IA, USA.

Bioeconomy Institute, lowa State University, Ames, IA, USA.

${ }^{4}$ Economics Department, lowa State University, Ames, IA, USA.

5 USDA-ARS, Madison, WI, USA.

Department of Bioproducts and Biosystems Engineering, University of Minnesota St Paul, MN, USA

${ }^{7}$ Biological Systems Engineering, University of Wisconsin, Madison, WI, USA.

USDA-ARS, Lincoln, NE, USA

${ }^{9}$ Agronomy Department, Purdue University, West Lafayette, IN, USA.

*Author for correspondence: kjmoore@iastate.edu
}

Taylor \& Francis Group 


\section{Key terms}

Biochar: A product of fast pyrolysis and a useful soil amendment. Biochar is composed primarily of condensed aromatic carbon but also contains most of the plant nutrients that are harvested with the biomass crop.

CenUSA Bioenergy: A Coordinated Agricultural Project (CAP), 'Sustainable Production and Distribution of Bioenergy for the Central US: An Agro-ecosystem Approach to Sustainable Biofuels

Production via the Pyrolysis-Biochar Platform' supported by USDA-NIFA AFRI CAP, Project \#2010-05073.

Corn/Soybean Belt: An agricultural region in Midwestern USA where corn (Zea mays L.) and soybean (Glycine max (L.) Merr.) are the dominant crops. This area extends from eastern Nebraska to western Ohio and from northern Missouri into southern Minnesota.

Crop biomass: All of the above ground dry matter produced by a crop and may include grain as well as vegetative structures.

Fast pyrolysis: Rapid thermal decomposition of biomass at temperatures in the range of $400-500^{\circ} \mathrm{C}$ and in the absence of oxygen to produce bio oil, flammable gases and biochar.

Lignocellulosic biomass: It is generally composed of leaves and stems, but can also include other vegetative structures associated with grain development such as husks and cobs when applied to crop residues. Chemically, it consists primarily of cellulose, hemicellulose and lignin.

Marginal land: For the purposes of this article, marginal land is defined as land that is not well suited to annual tillage because of erosion potential and that which is only marginally profitable for production of row crops. The former category is land that is typically in permanent vegetation or enrolled in conservation programs. The latter category is land that moves in and out of production based on the prevailing markets for commodity crops because profit margins for producing crops on it are narrow when compared to prime

cropland.

Solvolysis: Thermal interaction of a solvent with a solid or liquid reactant to produce chemical products in which the solvent can both dissolve reactants and products and participate in the chemical reactions. quality. The estimate is that there are approximately 40 million acres of land within the Central US region that could be shifted from either row crop production or permanent pasture to production of perennial energy crops with net environmental benefits making agriculture more sustainable [49,53]. For example, research in Iowa has demonstrated that growing perennial vegetation in $10 \%$ of small watersheds where the remaining land was in crop production, reduced sediment loss by $90 \%$ and substantially reduced losses of $\mathrm{P}$ and $\mathrm{N}$ [22].

\section{- Intellectual and technical focus}

Over the past five years CenUSA has laid the scientific groundwork and through educational and extension programming assisted in development of a regional system (Figure 1) for producing advanced transportation fuels derived from perennial grasses grown on land that is either unsuitable or marginal for row crop production. Recognizing that sustainable production of bioenergy and bio-based products requires a systems approach, CenUSA has addressed essential components along the supply chain associated with producing biofuels and bio-based products from herbaceous perennials grown on marginal land. From germplasm to harvest, the building blocks of the supply chain continuum are: (1) development of cultivars and hybrids of perennial grasses optimized for bioenergy production, (2) development of sustainable production systems that optimize perennial biomass yields and ecosystem services, (3) creation of flexible, efficient and sustainable logistics systems, (4) identification and characterization of sustainable bioenergy systems to achieve social, economic and environmental goals and understand socioeconomic and environmental consequences of perennial bioenergy systems, (5) identification of germplasm characteristics amenable to pyrolytic conversion and evaluate performance of pyrolytic biofuels, (6) evaluation of policy, market and contract mechanisms to facilitate broad adoption by farmers, and (7) development of procedures for managing risks and protecting health for each component of the biofuel production chain.

CenUSA's cross-cutting elements of education of undergraduate and graduate students, extension and outreach to engage stakeholders, and commercialization serve to unite elements of the supply chain.

\section{- Geographical focus}

CenUSA Bioenergy focuses on the Central US and more specifically on crop management zones 1, 4 and 16 as described by NRCS [50] (Figure 2). This region encompasses a high concentration of prime cropland and benefits from a humid continental climate. Annual precipitation varies to some extent in an east-west gradient across the region, but is generally sufficient for dryland crop production [4]. More pronounced are seasonal temperature gradients that occur along a north-south axis and influence the length of the growing season and severity of winter. The region encompasses USDA hardiness zones 3 to 5 with growing seasons ranging from 120 to 210 days [83]. Native vegetation is predominantly tallgrass prairie throughout much of the region with deciduous forest becoming more dominant to the east [2]. The soils in this region vary widely in productivity, but in general are inherently fertile [51]. These climatic and edaphic characteristics combine to create and define one of the world's most productive agricultural regions [84].

The following sections highlight CenUSA's contributions to the value chain and system required to produce bioenergy crops and products on land that is marginal for row crop production.

\section{Feedstock improvement}

The primary perennial energy crops being developed and evaluated are switchgrass (Panicum virgatum L.), big bluestem (Andropogon gerardii Vitman) and indiangrass (Sorghastrum nutans (L.) Nash). Each of these species is present in the native flora of the region and is already used for forage and conservation purposes, with several million acres seeded in the Conservation Reserve Program (CRP). More importantly, plant breeding and agronomic research on each of these crops has been in progress specifically for bioenergy production since 1990 and cultivars developed for this purpose have recently become available [78].

CenUSA and USDA-ARS Lincoln, Nebraska, have recently announced the release of Liberty [78], a new switchgrass cultivar that produces excellent biomass yields for bioenergy. Although Liberty was nearly two 


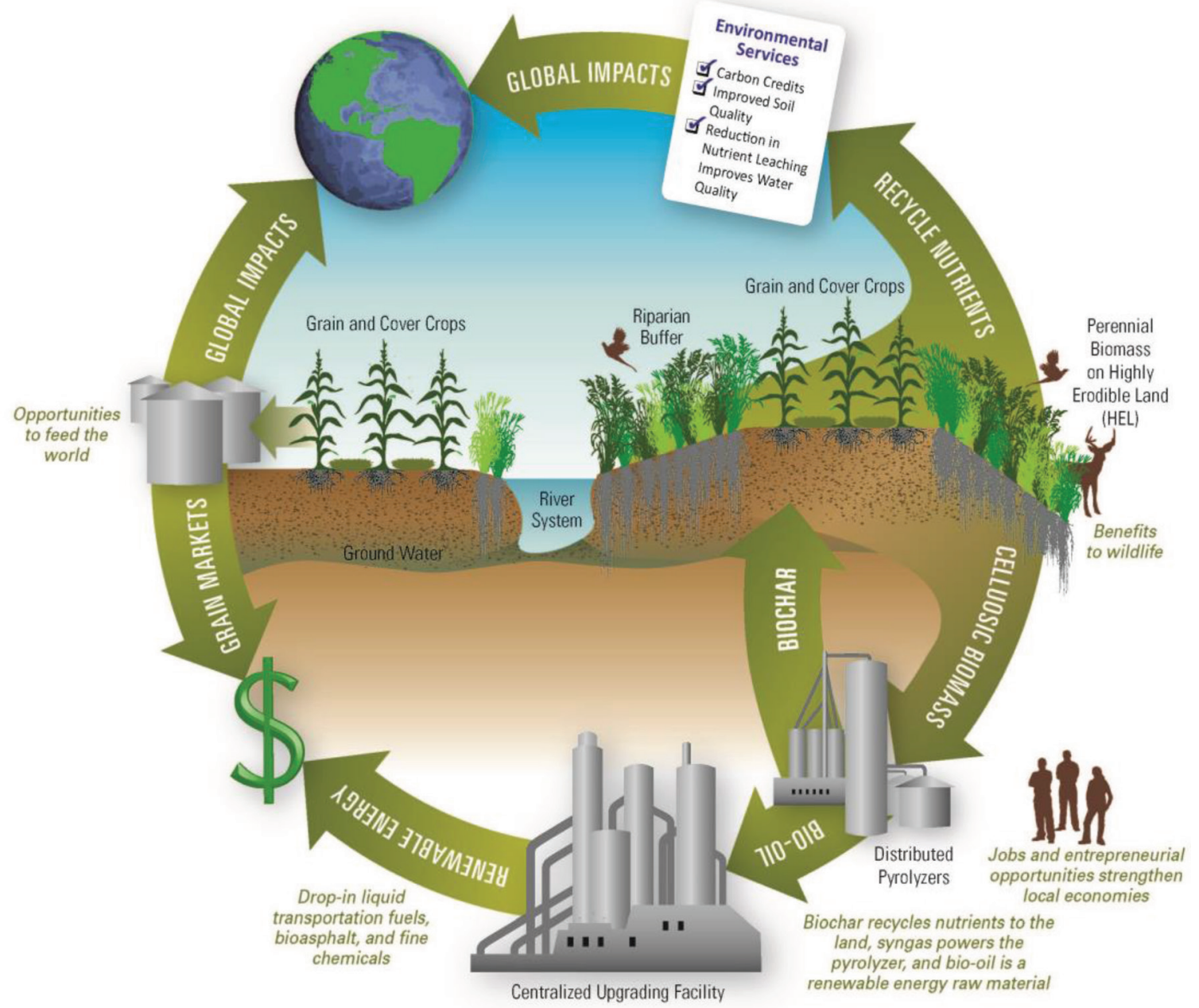

Figure 1. A systems view of CenUSA's vision of a potential biofuels system where perennial biomass grown on highly erodible land (right, center) is feedstock for distributed pyrolyzers. Biochar is returned to the soil and biooil is further upgraded in a centralized facility (bottom, center). Recycle of nutrients provides ecosystem services (top, center) with positive global environmental impacts. Farmers and local economies benefit. Drawing by Chris Hobbs.

decades in development, CenUSA made possible the extensive and intensive field trials that brought its release to fruition. Liberty's biomass yields in trials in Nebraska and Illinois are about $25-45 \%$ greater than for the best previously released cultivars adapted to the region. In multi-year trials at Mead, NE, and DeKalb, IL, both in USDA Plant Hardiness Zone 5, Liberty produced 8.1 and 7.3 tons/acre biomass, respectively, which was 1.5 to 2.5 tons/acre greater than the previously released upland cultivars adapted to the region. It has also produced high yields at testing sites throughout Wisconsin.

Early results from CenUSA genetic studies indicate that the increases made for biomass yield between 1992 and 2012 are expected to reduce farm-gate production costs by US $\$ 22-33$ per ton [12]. This is significant because economic studies indicate that long-term sustainability of switchgrass biomass production for energy will require some reduction in farm-gate prices $[41,55]$. In addition to increasing stable long-term biomass yield via adapted cultivars $[8,13]$, biomass quality traits such as resistance to disease, insects or environmental stresses contribute to breeding objectives, particularly when the targets and conversion platforms are clearly defined and laboratory methods are readily available [61].

Feedstock improvement, as exemplified by the release of Liberty, is driven by genetics and breeding principles and practices. Genetic studies performed by CenUSA researchers and others have established a number of important and fundamental characteristics of switchgrass, such as self-incompatibility and predominant 


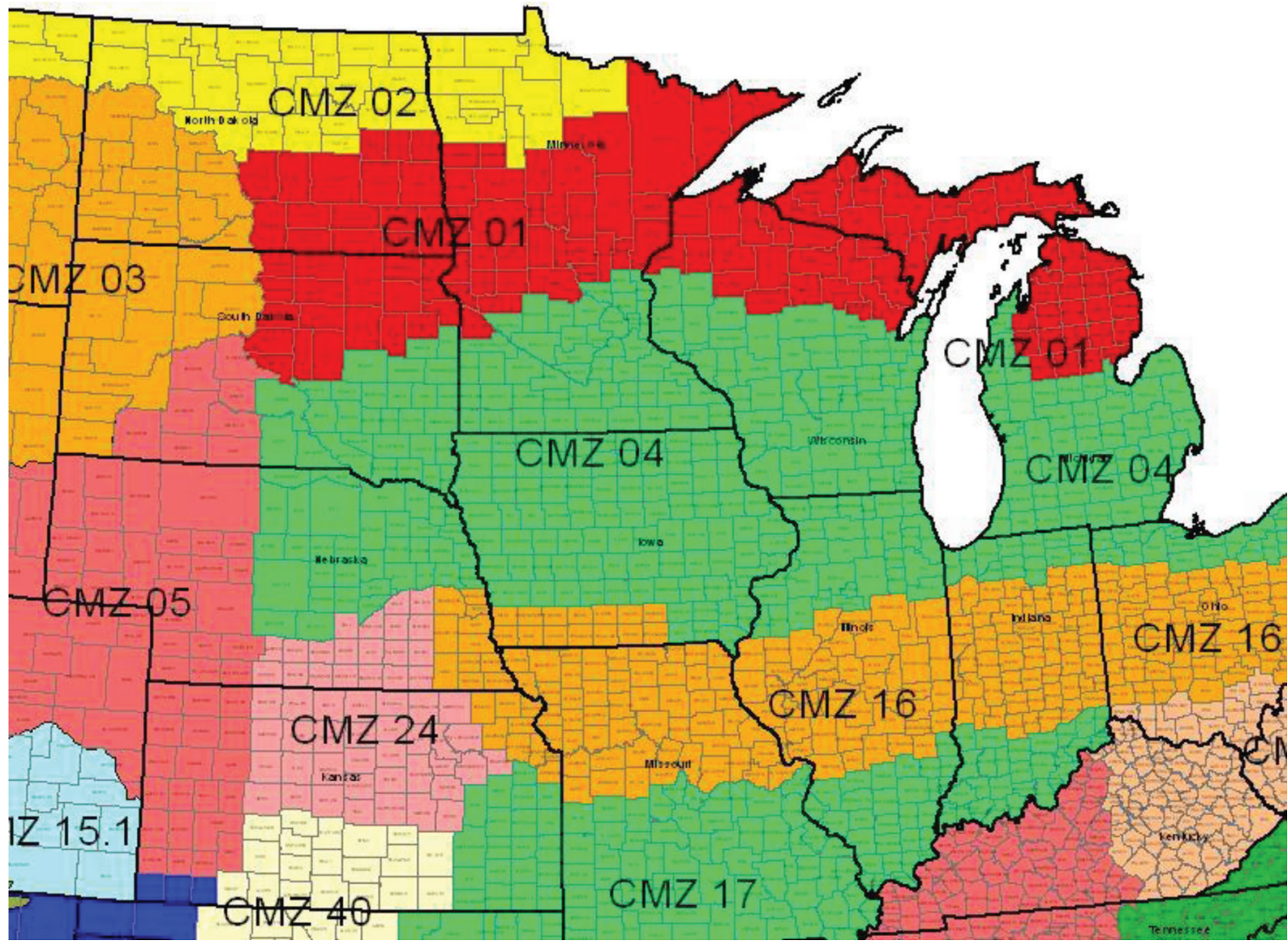

Figure 2. Crop management zones for the North Central US. CenUSA focuses on crop management zones 1, 4 and 16. Source: USDA-NRCS (2014).

outcrossing behavior, polyploidy with two highly homologous genomes, strong pollination and gene flow barriers between tetraploid and octoploid genotypes, and strong geographic differentiation of genotypes, especially with regard to the two principal ecotypes, upland and lowland $[8,13]$ and latitude or origin. Most breeding methods are fairly straightforward: collect seeds from prairies and cultivars, establish nurseries that consist of many thousands of individual plants, select the most desirable plants for crossing, make crosses or polycrosses to advance to the next generation of seed, and begin the process again. Using this general model for recurrent selection, genetic improvements accrue at a slow and steady pace, averaging 1 to $3 \%$ per year, resulting in new and improved cultivars every few years [76,79].

Figure 3 illustrates how large gains in biomass yield are associated with the proper matching of cultivars to their adaptation zones, combined with some initial generations of selection for biomass yield and adaptation traits.

Classical breeding and selection began with the use of seeds from locally adapted populations and cultivars, generally the upland ecotype in the northern
US and the lowland ecotype in the Southern US. It is traditionally recommended that cultivars should not be moved more than one hardiness zone north or south of their origin, due to the potential that lack of adaptation to a region will adversely affect survivorship and productivity $[8,13]$. Southern populations are very late in flowering and have insufficient tolerance to extreme cold temperatures of the northern US, while northern populations flower extremely early and suffer from sensitivity to heat, reducing their yield potential in the Southern US $[10,11]$. A review of cultivar evaluations, ranging from Wisconsin to Texas, showed a very strong yield advantage of lowland ecotypes compared to upland ecotypes. However, that yield advantage was reversed at the Illinois-Wisconsin border, where lowland ecotypes were unable to survive for more than 1 or 2 years.

The USDA-ARS breeding programs in Lincoln, Nebraska, and Madison, Wisconsin, have focused on selecting for winter hardiness within southern populations evaluated at northern locations. Breeding for cold tolerance within lowland ecotypes is gradually making them adapted to Plant Hardiness Zones 4 and 


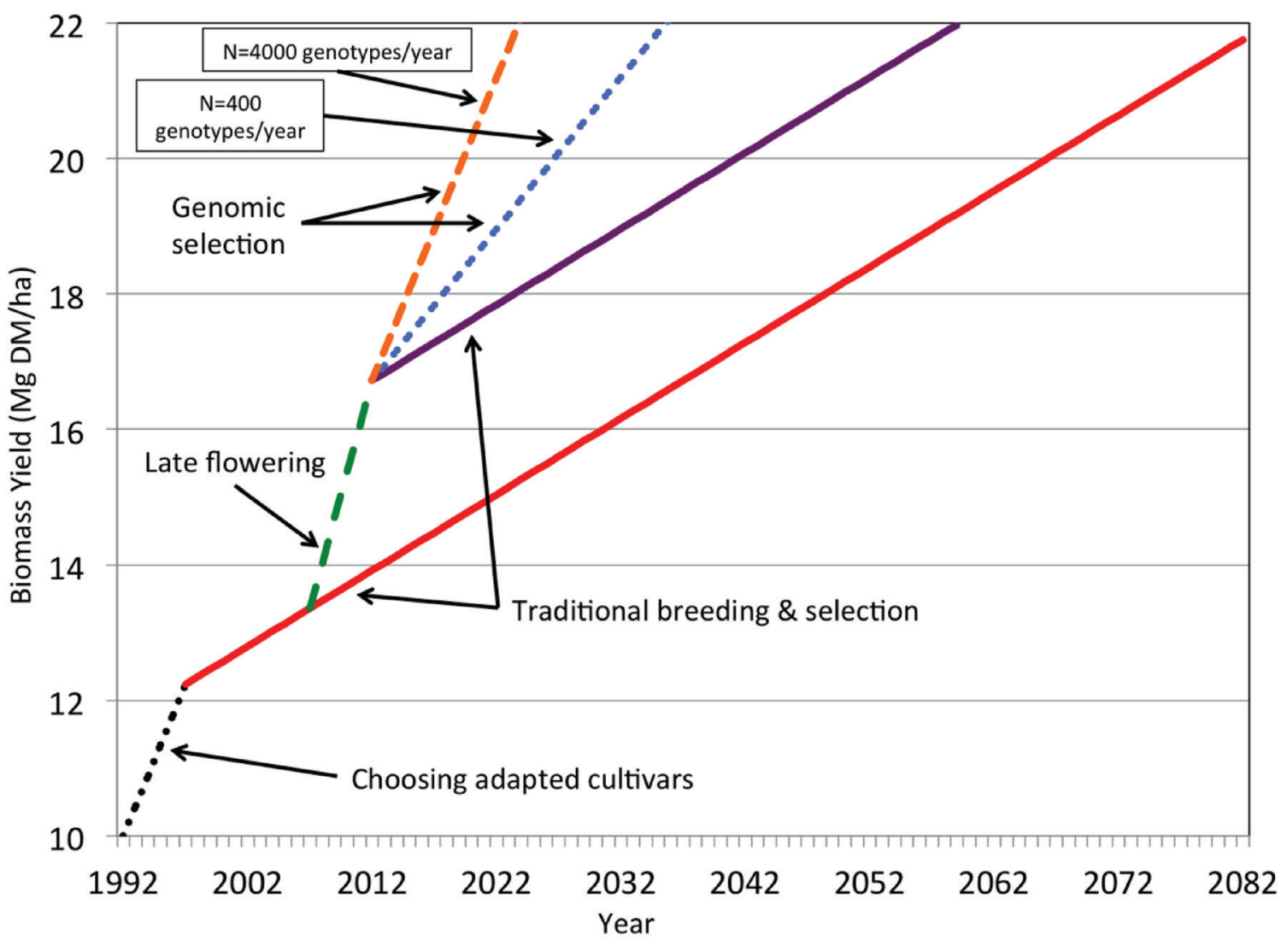

Figure 3. Real and projected timelines for genetic improvement of switchgrass biomass yield for US Hardiness Zones 3 through 6, based on four phases of breeding: (dotted black line) the choice of adapted cultivars as initial source material; (solid red and black lines) traditional breeding and selection; (dashed black line) incorporation of the late-flowering trait into northern-adapted germplasm; and (dashed red and blue lines) the use of genomic selection to accelerate recurrent selection.

5 of the northern USA, allowing breeders to use the late-flowering trait as a mechanism to capture a 30 to $50 \%$ biomass yield advantage that is taken for granted in the Southern US (Figure 3). For example, breeding for winter survival and biomass yield within the cultivar Kanlow resulted in a 32\% increase in survivorship and a $21 \%$ increase in biomass yield in Plant Hardiness Zones 4 and 5 [12].

Hybrids between upland and lowland ecotypes are a relatively new mechanism to combine the best traits of both ecotypes and expand the breadth of adaptation of a new cultivar. Hybrid cultivars are capable of combining the late flowering and high biomass yield of the lowland ecotype and the winter hardiness and cold tolerance of the upland ecotype in a single population. Hybrids between Summer (upland) and Kanlow (lowland) were selected through three generations for survivorship and biomass yield, resulting in superior performance compared to either parent at a range of locations that spanned Plant Hardiness Zones
3 through 5 (Table 1). The hybrids possessed a broader adaptation range than either of the parent cultivars and increased yield by 32 to $54 \%$ compared to the parent cultivars [77]. Future breeding efforts in Nebraska and Wisconsin are heavily leveraged toward the use of hybrid populations for continuing to create novel and significant genetic improvements to switchgrass (see Future Perspectives).

\section{Feedstock production on marginal land}

The species being evaluated are native to the US, have a long research history, pose low probability for becoming invasive, and have been planted on millions of acres of marginally productive cropland enrolled in CRP. Advantages include well-established production practices, ability to thrive in marginal soils, and high yield. In addition to biomass energy, perennial $\mathrm{C} 4$ grasses provide desirable conservation attributes like increasing wildlife habitat, controlling erosion, and sequestering carbon $[40,59]$. 
Table 1. Mean biomass yield and ground cover of Summer upland switchgrass, Kanlow lowland switchgrass, and Kanlow x Summer hybrid populations evaluated at four locations in Illinois and Wisconsin, including latitude and hardiness zone (HZ) of the evaluation location.

\section{Evaluation Site}

DeKalb, IL Arlington, WI Marshfield, WI Spooner, WI Population $42^{\circ} \mathrm{N}, \mathrm{HZ} 5 \mathrm{~b} \quad 43^{\circ} \mathrm{N}, \mathrm{HZ} 5 \mathrm{a} \quad 45^{\circ} \mathrm{N}, \mathrm{HZ} 4 \mathrm{~b} \quad 46^{\circ} \mathrm{N}, \mathrm{HZ} 3 \mathrm{~b}$ Mean

\begin{tabular}{|lrrcrr|}
\hline \multicolumn{5}{c|}{ Biomass Yield $\left(\mathrm{Mg} \mathrm{ha}^{-1}\right)$} \\
\hline Summer & 8.48 & 7.24 & 8.31 & 9.20 & 8.31 \\
\hline Kanlow & 9.20 & 4.57 & 3.16 & 2.52 & 4.87 \\
\hline $\begin{array}{l}\text { Kanlow } \mathrm{x} \\
\text { Summer }\end{array}$ & 14.41 & 9.89 & 10.62 & 12.60 & 11.89 \\
\hline \multicolumn{5}{|c}{} & Ground Cover (\%) \\
\hline Summer & 92 & 82 & 92 & 100 & 91 \\
Kanlow & 82 & 30 & 56 & 10 & 45 \\
\hline $\begin{array}{l}\text { Kanlow } \mathrm{x} \\
\text { Summer }\end{array}$ & 94 & 93 & 91 & 100 & 95 \\
\hline
\end{tabular}

\section{- Managing environmental impacts}

While an ever-expanding knowledge of agronomic practices needed to grow switchgrass and other native perennial grasses for biomass is in hand, there is only a rudimentary quantitative understanding of the impact of these grasses on the environment when managed as a bio-feedstock. Several CenUSA locations have in place highly instrumented Systems Analysis plots. In addition to measuring agronomic performance, they permit systematic collection of data on greenhouse gas emissions [68], loss of soil and nutrients to sub-surface waters via tile lines and surface waters via erosion [75], and biogeochemical cycling of carbon and nitrogen in the plants/soils [7]. At most locations, corn for grain is included as a control production system against which the environmental performance and associated ecosystem services of the biomass production systems are compared. Large reductions in nutrient losses and greenhouse gas emissions following the conversion of fields from corn production to perennial biomass systems have been reported. These data are critical to economic analyses and Life Cycle Assessments that will characterize overall system performance and lead to informed policy and production practices.

\section{- Challenges to production practices}

Production practices for switchgrass for bioenergy have been developed during the past 20 years and switchgrass is widely recognized as a sustainable biomass feedstock on land that is marginal for annual crop production [43]. Best management practices have been developed for switchgrass establishment and management in the Great Plains $[43,44,45,82]$ and CenUSA researchers have developed best management practices and extension guidelines for warm-season perennial grass feedstocks in the Great Plains and Midwest $[42,46,47]$.
Perennial warm-season grasses historically have been difficult to establish. Consequently, one of the challenges to growing perennial grasses is overcoming the perception of difficult and slow establishment. CenUSA researchers have investigated improvements in the establishment of perennial grasses such as the use of grass drills that place seeds at specific depths for minimum-till establishment, determining optimal seedbed preparation and seeding depths, and use of registered herbicides for weed control. These improvements, when coupled with advancements in seed quality determination and improved knowledge on the time of year to plant, has greatly improved the establishment of perennial grasses [42].

For example, the proper time to plant requires suitable soil temperatures and the greatest opportunity for precipitation [42]. If precipitation is adequate, these advancements in management facilitate rapid and uniform establishment with a realistic seeding year goal of harvesting $50 \%$ of the yield potential of the cultivar after frost in the planting year and harvesting $75-100 \%$ of the yield potential in the first full growing season after planting [42].

Weed control in perennial warm-season grass feedstocks is divided into two phases: establishment and management. Weed control is mandatory in the establishment phase if rapid stand establishment is desired. Weed competition during the planting year, especially from grassy weeds, is a major reason for delayed establishment in perennial warm-season grasses $[45,80]$. Failure to obtain a fully successful grass stand during the planting year limits yield in post-establishment years and decreases revenue [55]. Warm-season grasses have different herbicide tolerances. During the establishment phase, weed control is inexpensive and accounts for only $5-10 \%$ of total establishment cost. Weed control is less critical in the management phase and is needed only one or two times every 5 years in well-established stands harvested after frost.

Nitrogen fertilizer application is not recommended during the planting year because $\mathrm{N}$ encourages weed growth [45]. However, in established stands, $\mathrm{N}$ fertilizer is necessary for high yield and the amount applied should be based on available soil $\mathrm{N}$, anticipated biomass yield, and when harvest will occur. Harvesting biomass removes $\mathrm{N}$ and this $\mathrm{N}$ must be replaced to meet future plant growth. Perennial warm-season grasses harvested after frost typically contain about $0.6 \% \mathrm{~N}$. Consequently, about $6 \mathrm{~kg}$ of N ha ${ }^{-1} \mathrm{yr}^{-1}$ should be applied for each $1 \mathrm{Mg}$ $\mathrm{ha}^{-1}$ of anticipated biomass yield [42]. Phosphorus and $\mathrm{K}$ are generally adequate for warm-season grass growth on most cropland soils [58,85], but switchgrass has responded to fertilizer $\mathrm{P}$ if soil-test $\mathrm{P}$ is low or the soil on the site is very acidic (i.e., $\mathrm{pH} 4.3$ to 4.9$)$ [81]. 
- Potential uses of the biochar co-product

Biochar, a co-product of fast pyrolysis, is being evaluated for its agronomic and environmental value as a soil amendment on land planted to continuous no-tillage corn and on fields being seeded to perennial bioenergy crops. Assessments include the impact of biochar amendments on stand establishment, crop yields, soil carbon sequestration, greenhouse gas emissions, and various measures of soil quality.

Biochar is composed primarily of condensed aromatic carbon but also contains most of the plant nutrients that are harvested with the biomass crop. Biochar contains well over $90 \%$ of the potassium, phosphorous, calcium and magnesium and as a soil amendment recycles these nutrients, increases soil organic carbon levels, and increases the ability of soils to retain water and nutrients against leaching $[32,33,39]$. Furthermore, the slow turnover of biochar carbon in the soil results in net carbon sequestration $[33,37]$, hence the biomasspyrolysis-biochar system has the potential to produce carbon negative energy products.

The presence of organic bases, carbonates, and to a lesser extent hydroxide components of biochar, means that biochar is a liming agent. The calcium carbonate equivalent values of biochar vary substantially depending on feedstock and thermochemical processing conditions, but are typically between 5 and 20 . These positive impacts on soil quality can improve crop yields, particularly on marginal and degraded soils $[3,69]$.

The need to incorporate biochar into soils through tillage precludes the application of biochar on established perennial biomass crops. Consequently, it is anticipated that the biochar co-product will be applied primarily on adjacent crop lands, however, biochar could also be applied to fields being converted to bioenergy crop production prior to seeding.

\section{Feedstock logistics}

CenUSA has found that the factor of feedstock logistics is of paramount importance in determining the economic feasibility of converting biomass from perennial grasses into biofuels and bioproducts. This is because perennial grasses used as biomass feedstocks have almost no onfarm value-added processing. Thus it is imperative that costs of logistics be minimized so profits can be realized. An ideal feedstock would meet the biorefiner's physical and chemical specifications at a cost that ensures profits throughout the entire value chain. CenUSA has examined feedstock logistics including the unit operations of harvest, handling, storage, transport, and pre-conversion processing. The research has focused on in-field operations. Although, no research is being conducted on transportation from the field to the refinery, the economics and life cycle implications of these operations are considered in the modeling components of the project. What has been learned about each of these unit operations in the field research is described below.

\section{- Harvest}

Although yields of biomass perennial grasses are typically 2-3 times those of forage crops, most forage cutting, chopping and baling equipment can be used without modification to harvest biomass crops. Multiple cuttings of biomass grasses typically result in 30 to $40 \%$ greater annual yield than single-cut systems [66,73]. However, the greater yield does not offset the added costs of multiple cuttings, so single-cutting systems are typically employed. Harvest timing affects yield, stand persistence, weed control, and feedstock chemical composition. With a single-cut system, there is a reduction in yield of $1-15 \%$ when harvest is delayed from late-summer to late-fall [66]. When the biomass grasses are left standing over winter and harvested in the spring, dry matter yields were further reduced by 20 to $40 \%$ due to senesce of leaf tissue, lodging and harvest losses $[1,66]$. However, spring harvest reduces the concentration of ash and undesirable minerals, which may be desirable when thermo-chemical conversion is planned [1]. In northern climates, spring harvest will be challenged by late snow cover, wet fields, soil contamination from lodging, and a short window of opportunity for fertilization and weed control.

\section{- Handling}

Standing moisture of grasses harvested in the late fall will typically be $55-65 \%$ wet basis (w.b.) so field drying is required to achieve storage moisture of less than $20 \%$ (w.b.). A short field drying time promotes fewer losses and more uniform composition. Although drying to harvest moisture is possible in $2-3$ days [66,67], in northern climates, late-fall drying is challenged by short daylight length, low ambient temperatures and frequent poor weather. Faster drying is promoted by conditioning the stem to provide a moisture egress and spreading the crop as widely as possible to fully capture the limited available solar insolation.

CenUSA has developed a protocol to reduce field drying to one day after cutting while achieving consistent harvest moisture. This involves a single-pass mowing operation that combines intensive conditioning (by crushing and shredding) and tedding to full cut-width [67].

Standing moisture of biomass grasses is typically less than $15 \%$ (w.b.) when harvested in the late spring, so the grasses could be harvested at the same time as cutting [66]. Using a forage harvester with a direct-cut header would allow single-pass harvesting, reducing costs by eliminating field operations such as mowing and raking/ merging. A single-pass mowing and baling combination has also been demonstrated in spring harvest [16]. 
Density affects the cost of bale aggregation, handling and transport, and these operations can account for more than $40 \%$ of biomass logistics costs [14]. Weight limited transport (e.g., packing a truck with as much weight as it can legally carry) can only be achieved when bale density is about $240 \mathrm{~kg} \bullet \mathrm{m}^{-3}$, but until recently large round or square bale density has been much less than this, more typically $160-190 \mathrm{~kg} \bullet \mathrm{m}^{-3}$ [66]. The low density of bales is because biomass grasses are harvested quite mature, so they have large, stiff stems which resist compressive forces, limiting achievable density. Current efforts to increase bale density have concentrated on large square balers.

Manufacturers have increased bale density by reconfiguring balers with larger flywheels, greater capacity drivelines, longer compression chambers, greater chamber convergence forces, more knotters, and twostage plungers that divide the plunger impact into two steps, increasing the applied pressure [30]. Taken together, these changes have resulted in grass bale density improvements of $10-20 \%$, so that weight limited transport is approached but not yet achieved. However, high-density balers are more expensive than conventional balers, so harvest costs will be greater. Although few design changes have been developed to increase round bale density, a pre-cutter that resides between the round baler's pick-up and bale chamber has been used to size-reduce the long grass stems, making it easier to pack material into the bale and increase bale density by up to $10 \%$ [65]. However, competitive perennial grass logistics costs can only be achieved by continued efforts to improve bale density. Given the challenges and costs of increasing bale density at harvest, post-harvest densification should be investigated, especially for round bales which will likely be the dominant bale form on marginal land.

\section{- Storage}

Conservation of the value of perennial grasses during storage is critical to feedstock profitability. Feedstock storage losses are minimized by low harvest moisture and minimizing exposure to precipitation during storage. Chopped grasses or large square bales must be stored indoors or under cover (i.e., tarps, bags, covered bunks) to avoid exposure to precipitation. These storage options are often more expensive than outdoor storage, however conservation can be excellent with losses of $1-3 \%$ of DM if initial moisture is less than $20 \%$ (w.b.) $[28,60,66]$. Round bales shed precipitation and so lowcost outdoor storage is possible, although losses will be $2-15 \%$ of DM depending upon precipitation amount, length of storage, type of bale wrap, and ground preparation $[28,60,66]$. Alternatives such as wrapping with breathable-film or stretch-film that allow round bales to be stored outdoors with exposure to precipitation are being explored as part of this research.

\section{- In-field transportation}

The cost of field aggregation of bales after harvest is influenced by such variables as field shape and size, bale spatial location, yield, bale row spacing, collection paths, and aggregation strategies [24]. Accumulation during baling can place bales into strategically placed groups that not only reduce time for aggregation but reduce field traffic at removal. A round bale accumulator was evaluated as part of this research. When grass yields were $2-4 \mathrm{Mg} \mathrm{DM} \bullet \mathrm{ha}^{-1}$, bale accumulation reduced aggregation time and distance by $30 \%$ and $44 \%$, respectively [64]. Time and distance advantages were negligible when yields were greater than $8 \mathrm{Mg} \mathrm{DM} \bullet \mathrm{ha}^{-1}$.

\section{- Pre-conversion processing}

No matter the conversion process, perennial grasses must be size-reduced prior to conversion into biofuels or bioproducts and size-reduction is a significant fraction of the total feedstock logistics cost. Size-reduction is needed to increase the specific surface area so that conversion can take place more rapidly and with higher yields. Size-reduction is typically a multi-step process where initial gross size-reduction to $10-30 \mathrm{~mm}$ is followed by final size-reduction to $0.2-2 \mathrm{~mm}[19,29]$. Gross size-reduction of baled biomass is typically accomplished with a hammer mill or horizontal grinder. As an alternative, perennial grasses can efficiently be sizereduced at harvest using a forage harvester, but low bulk-density challenges economical transport and storage. The uncompacted bulk-density of chopped dry biomass grasses is typically $80-100 \mathrm{~kg} \bullet \mathrm{m}^{-3}[17,20]$. Bales have much greater density, which is why this harvest method is currently preferred. However, bale processing inside the biorefinery is expensive and often not considered a core activity of the biorefinery. Although size-reduction by chopping with a forage harvester or by tub-grinding bales produced similar particle size $(\sim 10 \mathrm{~mm})$, post-storage bale grinding required more than twice the energy of chopping a harvest ( $\sim 70$ vs. $\sim 160 \mathrm{MJ} \times\left(\mathrm{Mg} \mathrm{DM}^{-1}\right)$ [65]. As part of the CenUSA project, research efforts are underway to overcome the challenges of low-bulk-density chopped perennial grasses.

\section{Modeling system performance}

Moving the bioenergy industry toward greater sustainability requires careful consideration of the life cycle impact of various biomass production options and their placement on the landscape. CenUSA is conducting detailed analyses of feedstock production options [27] and an accompanying set of spatial models 
to enhance the ability of policymakers, farmers, and the bioenergy industry to make informed decisions about which bioenergy feedstocks to use, where to produce them, what environmental impacts they will have, and how biomass production systems are likely to respond to and contribute to climate change or other environmental shifts.

The CenUSA team has developed an integrated modeling framework $[62,63]$ based on the USDA National Resources Inventory sample points [49,52]. An economic model is linked to EPIC (Environmental Policy Integrated Climate) field-scale model and the Soil and Watershed Assessment Tool (SWAT) [18]. Land use in this modeling framework is driven by profitability and is thus a useful modeling system for evaluating the design of policies such as carbon trading, payment for ecosystem services and crop subsidies [74]. The CenUSA team is also using the InVEST (Integrated Valuation of Environmental Services and Tradeoffs) model [72] to estimate the provision of ecosystem services on the bioenergy production landscape and the Agro-IBIS (Integrated Biosphere Simulator) model to explore biophysical changes such as in net evapotranspiration and carbon flux.

These models are continually being adapted and refined as primary data from the work on feedstock improvement, feedstock production on marginal land, and feedstock logistics (see above) are collected and analyzed. For example, CenUSA scientists recently revised SWAT parameters and algorithms to better reflect biomass production data for perennial biomass grasses grown in the Central US [74]. The models are being used to perform a range of policy-relevant scenarios to measure the economic returns and ecosystem services produced on a landscape scale from the use of dedicated cellulosic feedstocks (e.g., switchgrass and mixtures of perennial grasses) including carbon, water quality, erosion, flood reduction, and biodiversity. This has led to the identification and characterization of sustainable bioenergy systems and the understanding of the socioeconomic and environmental consequences of emerging perennial bioenergy systems.

CenUSA is also developing biophysical landscapescale models to inform policy design via the tradeoffs between the production of food via corn grain, fuel production from corn grain and cellulosic production, and water quality. For example, small watershed models were used to study the potential for perennial grass feedstocks to reduce the frequency and magnitude of flood events in the Raccoon River Watershed in Iowa. A watershed based hydrologic model was used to represent changes in water movement under different land uses in the watershed. After developing a baseline scenario of flood risk based on the current land use and typical weather patterns, the effects of varying levels of increased perennials on the landscape were simulated under the same weather patterns. Change in stream flows and water quality were compared to the baseline scenario.

\section{Feedstock conversion}

CenUSA focuses on thermochemical processes for conversion of herbaceous feedstocks into products. Among the advantages of thermochemical processing are robustness towards different kinds of feedstocks, high rates of reaction, conversion in many cases of both the carbohydrate and lignin content of the feedstock, and the ability to produce drop-in fuels that are compatible with the present fuel infrastructure [23]. Many thermochemical processes also produce biochar as a coproduct, which has interesting prospects for promoting the recycling of nutrients, sequestering carbon, and improving soil fertility (see Feedstock Production on Marginal Land for details on biochar).

A wide variety of thermochemical processes are available, which can generally be classified as combustion, gasification, fast pyrolysis, and solvolysis [6]. Combustion is a familiar process that readily employs biomass as feedstock, but its products are limited to process heat and electricity. Gasification converts solid fuel into high-enthalpy gases, mostly carbon monoxide and hydrogen, which can be used in the production of liquid fuels as well as process heat and electricity. As currently envisioned, gasification requires operation at scales that are considered too large for the distributed feedstock supply under development in the CenUSA project.

Fast pyrolysis and solvolysis are processes that thermochemically deconstruct biomass into liquid products that that can be upgraded to biofuels and biobased chemicals. Both processes can be controlled to produce either bio-oil or sugar-rich products. Both fast pyrolysis and solvolysis are being explored in the CenUSA project because they lend themselves to distributed processing of herbaceous feedstocks and could be scaled according to the availability of feedstock in a region. As shown in Figure 1, a system of distributed pyrolyzers could be developed at a small regional scale to produce bio-oil that could be transported to a larger, more centralized refinery to accomplish the upgrading to gasoline or diesel fuel. Alternatively, Battelle is currently evaluating a pyrolysis unit small enough to be hauled on the flatbed of an 18-wheel truck. It is capable of converting 1 ton of biomass (in this case, pine chips) per day into $494 \mathrm{~L}$ (130 gallons) of wet bio-oil. Either a system of distributed small pyrolyzers or a mobile approach could greatly improve transportation logistics associated with the less energy dense biomass feedstock [86]. 


\section{- CenUSA's focus on fast pyrolysis}

Fast pyrolysis occurs when biomass is rapidly heated in the absence of oxygen to temperatures of $400-500^{\circ} \mathrm{C}$ in a few seconds with the goal of maximizing the production of liquids [5]. This usually requires the biomass to be ground to particles as small as $1 \mathrm{~mm}$ diameter and exposed to high heat fluxes in reactors that allow vapor and aerosol products to be rapidly quenched. As much as $70 \mathrm{wt} \%$ of the biomass is converted into bio-oil, yielding $560 \mathrm{~L} /$ ton (or 148 gallons/ton) of biooil. Bio-oil consists of an emulsion of lignin-derived phenolic oligomers in an aqueous phase of oxygenated organic compounds primarily derived from cellulose and hemicellulose. The bio-oil is highly acidic due to carboxylic acids, mostly derived from the acetyl group side chains of hemicellulose. The higher heating value of bio-oil ranges between $17 \mathrm{MJ} / \mathrm{kg}$ and $20 \mathrm{MJ} / \mathrm{kg}$ with liquid densities of about $1280 \mathrm{~kg} \mathrm{~m}^{-3}$. Fast pyrolysis can be manipulated to depolymerize polysaccharides to primarily monosaccharides, which can be separately recovered from the aqueous phase [31].

Over the past several years and with substantial support from state, federal, and industry sponsors, Iowa State University researchers have developed a system that allows recovery of bio-oil as stage fractions with distinctive chemical and physical characteristics [56]. These fractions include sugar-rich syrup, phenolic oligomers, and a carboxylate-rich aqueous phase. The syrup can be fermented to ethanol or other biochemical products and the carboxylates fermented to lipids [25].

\section{Marketing and markets}

CenUSA is developing a comprehensive strategy to address impacts to and requirements of markets and distribution systems, both critical to successful implementation and commercialization of a regional system of biofuels derived from perennials grown on land unsuitable or marginal for row crop production. Three unifying approaches are being developed: (1) the study and evaluation of farm-level adoption decisions, exploring the effectiveness of policy, market and contract mechanisms that facilitate broad-scale voluntary adoption by farmers; (2) evaluation of the impacts of the expanded advanced biofuel system on regional and global food, feed, energy and fiber markets; and (3) evaluation of potential biochar markets.

\section{- Challenges and drivers of farm-level adoption}

An important component in the development of a regional system of perennial grasses for biofuel is an understanding of the farm-level production decision when perennial grass for biomass harvest is one alternative that producers have in their land use and farm enterprise portfolio. Adoption will be voluntary; therefore, a primary challenge faced by perennial grasses in the Midwest arises from the economics of land use: market forces allocate land to its highest-return use. Particularly in recent years, historically high commodity prices and increases in trend-line yields for Midwest row crop production dominate other land use alternatives based on observed economic returns [15]. A second challenge is that farmers will need a substantial premium in excess of the return from growing annual crops to compensate them for the risks and lack of flexibility associated with a multi-year crop [87].

A survey of participants who attended Iowa State University's 2012 Integrated Crop Management Conference provided insight on how landowners view the prospect for perennial grasses in the Midwest. The participants were asked to identify the proportion of the acres they control that are on highly erodible lands, and while responses varied from $0 \%$ to $100 \%$, the average of those who responded was $15 \%$. They were asked to rank a list of "drivers" of switchgrass production to identify positive aspects of or influences on a producer's decision to adopt switchgrass production within the current landscape. Similarly, participants were provided a list of reasons believed to be negative aspects (challenges) of or influences on a producer's decision to adopt switchgrass production and asked to rank those "barriers" as to how they are likely to influence their decision to plant and grow a perennial grass energy crop.

Respondents viewed the opportunity to engage in an emerging market and the conservation and habitat provision of perennial grasses as the two most important or most influential reasons to adopt switchgrass production. The ability to get ahead of future regulation of agricultural production, to reduce nutrient use, and to pursue enterprise diversification are also relatively important determinants in the adoption decision. Respondents who ranked enterprise diversification or emerging market opportunities highest indicated that profitability is the key driver. Overwhelmingly, and not surprisingly, producers identify that the biggest barrier at this point is the lack of a current market for harvested grasses.

Conservation, diversification, and reduction in nutrient use were ranked well below the top factor. However, respondents who managed a high amount of highly erodible land ranked conservation and habitat provision as the biggest influence to using perennial grass systems, along with the desirability of a longer rotation strategy and emerging market opportunities. Concerning the barriers to the system, respondents with small amounts of highly erodible land ranked highest that a new production technology and longer rotation would be necessary. Respondents with the largest amount of highly erodible land also identified the requirement of a longer 
rotation along with uncertainty in leasing land as the biggest barriers.

\section{- Potential impacts on fuel and farm commodity markets}

The impact of mandated ethanol and biofuel production vis-à-vis the US renewable fuel standard (RFS) and the updated RFS2 on food and commodity markets is highly dependent on energy prices and biofuel policies. In a 2009 study, Hayes et al. [21] explored four biofuel policy scenarios and identified the expected impacts to fuel and commodity markets. Among their findings were that increased ethanol production beyond that mandated for corn ethanol will result in much lower ethanol prices due to the inability of the marketplace to absorb less than a ten percent ethanol blend. Ethanol production to meet the cellulosic biofuel mandate will damage the market for existing corn ethanol. This suggests that the ideal biofuel from this project be a fuel other than ethanol.

\section{- Potential impacts on biochar markets}

The current market value of biochar is approximately US $\$ 1000$ per dry ton, as it is being used primarily in niche markets including soil-less potting media in horticulture, mine land reclamation, organic farming, urban (backyard) gardens, remediation of urban brown fields, green roofs, and for the capture of nutrients and/or removal of contaminates from industrial and agriculture effluents. The current price of biochar is prohibitive for production agricultural applications; however the price is anticipated to drop sharply in the event of industrial scale production of biochar as these niche markets will be quickly saturated. Discounting environmental services, the direct agronomic value of biochar when applied on agricultural land used for continuous corn production in the upper Midwest is estimated to be between US\$38 and US\$106 per dry ton. This estimate was calculated by assuming that a farmer took out a 20 year loan at $5 \%$ interest rate to pay for the initial purchase and application of 10 tons per acre biochar and received a 6 to 12 bushel per acre corn yield increase with the price of corn ranging between US\$5 and US\$7/bushel. Substantial regional variation in the base agronomic value of biochar is anticipated depending on local soil properties, crops, and markets.

\section{Health and safety}

The US agricultural workforce was over 2 million strong in 2011. While not the largest workforce population for an industry in the US, it received the distinction as the most deadly industry with a worker fatality rate of 24.6 deaths per 100,000 workers [48]. This death rate is more than eight times the all-industry average death rate. The leading source of fatalities for agriculture, accounting for nearly one quarter, was machinery.

Adaptive changes for bioenergy feedstock production will have inherent differences from current agricultural production processes. These changes could greatly increase the potential of injury or death if not evaluated and protective countermeasures put in place. As an example, lands deemed unsuitable or marginal for row crop production often have a sloped topography that poses unique hazards to agricultural tractors and other machinery than land typically used for row crop production. Topographies different from where farmers normally operate their tractors and machinery can greatly increase their risk of an overturn injury; the leading cause of deaths among farmers. There are also unique dangers associated with dust while handling biofeedstocks, as well as the ever-present potential of a fire.

CenUSA's focus is on developing a risk assessment analysis for this project. Developing an in-depth risk assessment analysis will improve the understanding of risk connected to the most dangerous industries in the US. This analysis will be effective in identifying specific risks associated with single tasks to aid in developing interventions to improve safety.

\section{Education and outreach}

Although the education, extension and outreach programs of CenUSA cover the age range from $\mathrm{K}$ to gray, programmatic content is targeted to the project's stakeholders at each level. When appropriate, CenUSA features hands-on learning experiences, whether it be for agricultural co-op members, or for undergraduate students involved in internships. The goal is to help create tomorrow's leaders in bioenergy production.

\section{- Education at the university level}

CenUSA is engaged in four major activities: (1) development of coursework modules reflecting knowledge generated by the project's research; (2) offering structured 10-week, paid research internship experiences in project labs using as a model the highly successful National Science Foundation Research Experience for Undergraduates program; (3) holding a bi-annual twoweek summer Intensive Program, Native Perennial Grass Bioenergy, for graduate students affiliated with the project; and (4) conducting regular online seminars to link graduate students and advisors across the project. An important component of the education program is mentorship and, to that end, CenUSA has developed online training materials for mentors of undergraduate interns. Furthermore, team members are actively engaged in research to understand the qualities of mentorship that lead to outstanding experiences. 


\section{- Extension and outreach}

The CenUSA extension and outreach components are integrated across all project objectives and are structured to impact stakeholders, including agricultural producers, industry leaders, extension educators, government agencies, youth and the general public.

A series of CenUSA webinars have been developed and shared with extension educators and industry leaders. For example, a webinar titled "Thermochemical Conversion of Biomass to Drop-in Biofuels" (February 2013) provided participants with an opportunity to learn about thermochemical processes and the feedstock options. Survey results suggest a knowledge gain for participants in three areas: (1) preferred characteristics of biomass feedstocks for thermochemical processing; (2) thermochemical biomass processing pathways; and (3) commercial scale thermochemical biofuel plants.

A number of outreach activities have been conducted for industry leaders and farmers. For example, at the Iowa State University's 2012 Integrated Crop Management Conference, participants who attended a session on "Understanding the Economics of a System of Perennial Grasses for Bioenergy in the Central United States" learned about expected costs and returns of perennial grass production, storage, harvest and transport. A follow-up survey measured their perceptions of establishing switchgrass production systems (see Marketing and markets).

Another CenUSA extension and outreach educational program shared research being done on biofuels and potential aviation fuel outputs with farmers and industry leaders, and another has implemented a series of outreach activities for non-farm audiences about biochar using the highly successful Extension Master Gardener program as the dissemination and educational mechanism. For example, in 2012, the public was invited to the Iowa State University horticulture research and demonstration farms to see how biochar was an effective soil amendment in gardens and landscaping. Survey results from participants indicated there was a statistically significant increase in participants' intentions to learn more about biochar as a soil amendment, how to use it, and their intentions to tell others about its benefits.

CenUSA also leads outreach efforts for industry commercializing thermochemical processing of biomass. In 2012, CenUSA held a two-day workshop for 66 people from 10 companies and five feedstock suppliers, as well as CenUSA team members. Topics covered during the workshop included Impacts of Facility Scale and Location on Thermochemical Biorefinery Costs, Ideal Feedstock Characteristics for Thermochemical Processing of Biomass, and Ideal Feedstock Characteristics for Thermochemical
Processing of Biomass. Respondents to a survey following the workshop indicated an increase in their understanding of ideal feedstock characteristics for thermochemical processing. Another event was held for in conjunction with the Mississippi River Hypoxia Task Force, federal, state and US agency professionals, and environmental NGOs. The purpose of the meeting was to share information about the potential of perennial grasses to lower nutrient runoff to the Mississippi River.

\section{- Future perspectives}

This article began with a discussion of how policy in general, and the RFS in particular, is driving development of technologies for renewable and sustainable energy. There is no question that this will continue to be the case over the next decade, and the economic advantage of one renewable energy source over another will fluctuate with changes in incentives. Nevertheless, now at the project's mid-point, CenUSA has already demonstrated that biomass grown on marginal lands can be an important part of the US renewable energy portfolio.

More importantly, the project has uncovered future areas of research and technology development that will contribute to US competitiveness in biorenewable fuels. Some of these avenues of investigation are summarized here.

\section{- Germplasm to harvest}

Genomic selection techniques will advance the rate at which new feedstocks are developed. With improvements to genomic sequencing capabilities and technologies, it has become realistic to utilize information from the entire switchgrass genome in the selection process [9]. Genomic selection is a mechanism to utilize millions of single-nucleotide polymorphic (SNP) markers as an aid in improving the efficiency of genetic improvement programs. Calibration of SNP markers to reliable field data for quantitative traits allows breeders to develop predictive equations with sufficient robustness and reliability that they can be applied to seedlings grown in the glasshouse for two or three generations, rapidly accelerating the rate of genetic gain and allowing breeders to capture all of the genetic variation and heritability of the traits that comprise the principal goals of the breeding program. For example, routine evaluation of 400 genotypes per year, using genomic selection approaches, is expected to double the rate of genetic gain in a switchgrass improvement program, rapidly reducing the time required to reach the "holy grail" of $22 \mathrm{Mg} / \mathrm{ha}$ in dry biomass production (Figure 3). Increasing the annual output to 4000 genotypes per year would double the gain again, potentially allowing development of a cultivar with genetic potential for $22 \mathrm{Mg} /$ ha by 2024 . 
In addition to accelerated plant breeding strategies, much research and optimization remains to be done on perennial grasses. For example, research on $\mathrm{N}$ and $\mathrm{C}$ cycling in these candidate biomass systems is fragmented and incomplete [40]. Likewise, understanding crop water balance and optimizing water use efficiency will be essential to renewable biofuel success, as water is expected to be the single most limiting factor in the agro-ecozones in which US biofuel will be produced. Systematic comparisons of production potential and nutrient, water, and energy use efficiency for low-input polycultures, mixed grass-legume systems and managed switchgrass systems are essential for optimizing biomass production. Recycling nutrients harvested with biomass to adjacent crop lands through soil biochar applications [36] may enhance nutrient use efficiency at a landscape scale. Soil biochar applications may further enhance system sustainability by improving soil quality [34], reducing nutrient leaching $[35,39]$, sequestering $\mathrm{C}[70]$, and increasing yields especially on marginal and degraded soils [71].

Feedstock logistics remains a key element in determining the economic viability of biofuel and bioproducts derived from perennial grasses grown on marginal land. For example, increased machine capacity will be needed as agronomic research leads to even higher biomass yields and logistics improvements are needed to reduce costs. The energy advantages of chopping at harvest will only be realized by development of systems to store and transport chopped material at densities similar to bales [17].

Finally, it is important to account for the ecosystem services of emerging technologies such as a biofuel production from perennial feedstocks. They have the potential to provide significant environmental gains in the form of improved water quality (through significant reductions in soil erosion, phosphorus, and nitrogen losses) and reduced net carbon emissions. If society is to adopt policies that encourage and support development and implementation of these technologies, it is essential that the extent of environmental gains are documented and that policies are developed that achieve the greatest gains possible with limited tax payer dollars. This is challenging in the deployment of perennial feedstocks since the magnitude of environmental benefits will vary considerably depending on the location and land characteristics in which the feedstocks are produced.

To evaluate the effects of cellulosic biofuels at a very large landscape scale, a major component of the CenUSA modeling work involves development of datarich, spatially defined watershed models for the Upper Mississippi River Basin and the Ohio-Tennessee River Basin. The modeling framework, based on SWAT, InVEST, and Agro-IBIS models, will provide tools needed to study incentives and policies that target placement of switchgrass and other biofuel crops to specific landscape locations.

\section{- Postharvest conversion and markets}

The product stream from fast pyrolysis is rich and diverse and creates challenges and opportunities. For example, phenolic oligomers from fast pyrolysis contain vinyl and carbonyl reactive groups and have a tendency to polymerize. If the reactivity of the phenolic oligomers can be controlled or altogether prevented, it could find applications as diverse as production of carbon fibers or heating oil substitute, as well as improve prospects for hydroprocessing it to diesel fuel.

The carboxylates from fast pyrolysis also have applications in the production of gelled fuel (by blending with ethanol) and ketones. The phenolic oligomers, derived from depolymerization of lignin, exist as a viscous, low volatility material that is highly reactive due to the vinyl and carbonyl functional groups associated with the phenol moieties [54]. This reactivity causes the phenolic oligomers to polymerize when heated. Even storage at room temperature for several weeks can lead to polymerization. This behavior prevents phenolic oligomers derived from lignin to be employed as fuel or feedstock in many applications. However, this tendency to polymerize can be exploited in some applications, for example, in the production of bioasphalt or co-firing pellets where the polymerizing phenolic compounds bind together stone aggregate or crushed coal, respectively.

The product stream from pyrolytic conversion of biomass is one part of an entire system that involves changing agricultural priorities. Establishment of perennial grasses is not new to agricultural producers. Midwest participants in the USDA CRP have been planting mixed species of grasses, including switchgrass, since 1985. Therefore, many producers and researchers identify that a natural way to foster perennial grass production is to provide for it within the context of the CRP. CRP contracts are 10-year commitments and provide landowners with the ability to divert agricultural land from annual row crop production to perennial systems while receiving annual per-acre rental payments to do so. A modification of the current CRP could be implemented on a limited scale to allow producers to plant high-yielding varieties of switchgrass for harvest with a subsequent reduction in their CRP annual payment when harvesting the acres. Allowing CRP acres to transition to production of perennial grasses for harvest overcomes many of the barriers identified by producers including risk of market development, loss of revenue, and the long-rotation nature of this crop. From a public-good perspective, a 
well-structured transition can provide for much of the currently-realized benefits of the CRP at a reduced cost to taxpayers. A harvested-CRP program will undoubtedly reduce some of the wildlife benefits on acres that are not currently harvested; this benefit reduction needs additional quantification.

An alternative to CRP transition is to subsidize switchgrass production relative to corn stover. Kauffman and Hayes [26] show that this subsidy can be justified based on carbon emissions when carbon prices are in excess of US\$72 per ton.

\section{- Education, extension and outreach}

As feedstock yields improve and markets develop for perennial biomass crops, extension and outreach efforts will transition from awareness and knowledge mode to adoption mode. Extension programs will need to intensify and expand. Additional train-the-trainer events (for extension professionals, conservation leaders and agri-industry professionals) will need to be held. The fact sheets, videos, and training materials developed by the CenUSA project will be important tools to help producers adopt best practices for transitioning land to perennial biomass crops.

\section{Acknowledgement}

The authors would like to thank Lynn W. Jelinski (Sunshine Consultants, International) who served as managing editor for this paper. The paper benefited greatly from her ability to assemble the writings of multiple authors into a coherent whole.

\section{References}

1 Adler PR, Sanderson MA, Boateng AA, Weimer PJ, Jung HG. Biomass yield and biofuel quality of switchgrass harvested in fall or spring. Agron J. 98, 1518-1525 (2006).

2 Anderson, RC. Evolution and origin of the Central Grassland of North America: climate, fire, and mammalian grazers. J. Torrey Bot. Soc. 133, 626-647 (2006).

3 Biederman LA, Harpole SW. Biochar and its effects on plant productivity and nutrient cycling: a meta-analysis. Global Change Biol. Bioenergy 5, 202-214 (2013).

4 Brown RA, Rosenberg NJ, Hays CJ, Easterling WE, Mearns LO. Potential production and environmental effects of switchgrass and traditional crops under current and greenhouse-altered climate in the central United States: a simulation study. Agric. Ecosyst. Environ. 78, 31-47 (2000).

5 Brown RC, Brown TR. In: Biorenewable Resources: Engineering New Products from Agriculture (2nd Edition). Wiley, NY, 229-335 (2014).

6 Brown RC. Thermochemical Processing of Biomass. Wiley \& Sons Ltd, Chichester, UK (2011).

7 Burks, JL, Volenec J, Brouder S. Seasonal cycling and partitioning of $\mathrm{N}, \mathrm{P}$, and $\mathrm{K}$ in perennial bioenergy crops. Proceedings of the ASA-CSSA-SSSA Annual Meetings. San Antonio, TX, USA, 16-19 October 2011.

8 Casler MD, Mitchell RB, Vogel KP. Switchgrass. In: Handbook of Bioenergy Crop Plants (Vol. 2.) Kole C. Joshi, C. Shonnard D (Eds). Taylor \& Francis, NY,USA, 563-590 (2012).
9 Casler MD, Tobias CM, Kaeppler SM et al. The switchgrass genome: tools and strategies. Plant Genome 4, 273-282 (2011).

10 Casler MD, Vogel KP, Taliaferro CM et al. Latitudinal and longitudinal adaptation of switchgrass populations. Crop Sci. 47, 2249-2260 (2007).

11 Casler MD, Vogel KP, Taliferro CM, Wynia RL. Latitudinal adaptation of switchgrass populations. Crop Sci. 44, 293-303 (2004).

12 Casler MD, Vogel KP. Selection for biomass yield in upland, lowland, and hybrid switchgrass. Crop Sci. 53 (2014). (In press).

13 Casler MD. Switchgrass breeding, genetics, and genomics. In: Switchgrass. Monti A. (Ed). Springer, NY, USA, 29-54 (2012).

14 Cook DE, Shinners KJ. Economics of alternative corn stover logistics systems. ASABE Paper No. 1111130. St. Joseph, MI (2011).

15 Dumortier J, Kauffman N, Hayes D. Uncertainty competition and time to build in switchgrass production. Proceedings $17^{\mathrm{h}}$ ICABR Conference Innovation and Policy for the Bioeconomy. Ravello, Italy, 18-21 June 2013.

16 First Source Bioproducts. http://www. firstsourcebioproducts.com/ ( Accessed January 2014).

17 Funk L, Grieger L. Biomass energy crop densification evaluation. Prairie Agricultural Machinery Institute (PAMI) Project No. 21811R. Portage la Prairie, MB. (2012). http://www.ofa.on.ca/uploads/userfiles/files/ biomass_energy_crop_densification.pdf

18 Gassman PW, Reyes MR, Green CH, Arnold JG. The Soil and Water Assessment Tool: historical development, applications, and future research directions. Trans. ASABE 50(4), 1211-1250 (2007). doi: $10.13031 / 2013.23634$

19 Gil M, Gonzalez A, Gil A. Evaluation of milling energy requirements of biomass residues in a semi-industrial pilot plant for co-firing. Proceedings $16^{\text {th }}$ European Biomass Conference and Exhibition, Valencia, Spain, 2008. http://teide.cps.unizar.es:8080/pub/ publicir.nsf/codigospub/0497/\$FILE/ cp0497a.pdf

20 Groothuis, M, Womac A, Braswell G, Bitra V. Compaction experiences with bulk-format switchgrass in commercial transfer systems. ASABE Paper No. 1110819. St. Joseph, MI (2011).

21 Hayes D, Babcock B, Fabiosa J et al. Biofuels: potential production capacity, effects on grain and livestock sectors, and implications for food prices and consumers. J. Agric. Appl. Econ. 41, 465-491 (2009).

22 Helmers MJ, Zhou X, Asbjornsen H, Kolka $\mathrm{R}$, Tomer MD, Cruse RM. Sediment removal by prairie filter strips in row-cropped ephemeral watersheds. J. Environ. Qual.41, 1531-1539 (2012) . http://fargo.nserl.purdue. edu/rusle2_dataweb/RUSLE2_Index.htm

23 Huber, GW. Breaking the chemical and engineering barriers to lignocellulosic bio-fuels: next generation hydrocarbon biorefineries. A research roadmap for making lignocellulosic bio-fuels a practical reality (2008). http://www.ecs.umass.edu/biofuels/ Images/Roadmap2-08.pdf

24 Igathinathane C, Gustafson C, Archer D, Hendrickson J, Kronberg S. Effects of field variables on infield biomass bales aggregation strategies. ASABE Paper No. 121337357. St. Joseph, MI (2012). 
25 Jarboe LR, Wen Z, Choi DW, Brown RC. Hybrid thermochemical processing: fermentation of pyrolysis-derived bio-oil. Appl. Microbiol. Biotechnol. 91, 1519-1523 (2011).

26 Kauffman NS, Hayes DJ. The trade-off between bioenergy and emissions with land constraints. Energy Policy 54, 300-310 (2013).

27 Keeler BL, Krohn BJ, Nickerson TA, Hill JD. US federal agency models offer different visions for achieving renewable fuel standard (rfs2) biofuel volumes. Environ. Sci. Technol. 4, 10095-10101 (2013).

28 Khanchi A, Jones CL, Sharma B, Huhnke RL. Characteristics and compositional change in round and square switchgrass bales stored in South Central Oklahoma. Biomass Bioenergy 58, 117-127 (2013).

29 Kratky L, Jirout T. Biomass size reduction machines for enhancing biogas production. Chem. Eng. Technol. 34, 391-399 (2011).

30 Kuhn North America. 1290i Large Square Baler (2014). http://www.kuhnnorthamerica. com/us/range/balers/large-square-balers.html

31 Kuzhiyil N, Dalluge D, Bai X, Kim KH, Brown RC. Pyrolytic sugars from cellulosic biomass. ChemSusChem 5, 2228-2236 (2012).

32 Laird DA, Chang CW. Long-term impacts of residue harvesting on soil quality. Soil Tillage Res. 134, 33-40 (2013).

33 Laird DA. The charcoal vision: a win-win-win scenario for simultaneously producing bioenergy, permanently sequestering carbon, while improving soil and water quality. Agron. J. 100, 178-181 (2008).

34 Laird DA, Fleming PD, Davis DD, Horton R, Wang B, Karlen DL. Impact of biochar amendments on the quality of a typical Midwestern agricultural soil. Geoderma 158, 443-449 (2010)

35 Laird DA, Fleming PD, Karlen DL, Wang B, Horton R. Biochar impact on nutrient leaching from a Midwestern agricultural soil. Geoderma 158, 436-442 (2010).

36 Laird DA, Brown RC, Amonette JE, Lehmann J. Review of the pyrolysis platform for co-producing bio-oil and biochar. Biofuels Bioprod. Bioref. 3 , 547-562 (2009).

37 Lehmann, J. Bio-energy in the black. Front. Ecol. Environ. 5, 381-387 (2007).

38 Lehmann J, Czimczik C, Laird D, Sohi S. Stability of biochar in soil. In: Biochar for Environmental Management. Lehmann J, Stephen J (Eds). Earthscan, London, UK (2009).
39 Lehmann J, da Silva JPJr., Steiner C, Nehls T, Zech W, Glaser B. Nutrient availability and leaching in an archaeological Anthrosol and a Ferralsol of the Central Amazon basin: fertilizer, manure and charcoal amendments. Plant Soil 249, 343-357 (2003).

40 Liebig MA, Vogel KP, Schmer MR, Mitchell RB. Soil carbon storage by switchgrass grown for bioenergy. Bioenergy Res. 1, 215-222 (2008).

41 McLaughlin SB, Kszos LA. Development of switchgrass (Panicum virgatum) as a bioenergy feedstock in the United States. Biomass Bioenergy 28, 515-535 (2005).

42 Mitchell R, Schmer M. Switchgrass harvest and storage. In: Switchgrass, A Valuable Biomass Crop for Energy. Monti A (Ed). Springer, London, UK, 113-127 (2012).

43 Mitchell R, Vogel KP, Berdahl J, Masters RA. Herbicides for establishing switchgrass in the central and northern Great Plains. Bioenergy Res. 3, 321-327 (2010).

44 Mitchell RB, Wallace LL, Wilhelm W, Varvel G, Wienhold B. Grasslands, rangelands, and agricultural systems. Biofuels and Sustainability Reports, Ecological Society of America (2010).

45 Mitchell RB, Vogel KP, Sarath G. Managing and enhancing switchgrass as a bioenergy feedstock. Biofuels, Bioprod. Biorefin. 2, 530-539 (2008).

46 Mitchell R, Vogel KP, Sarath G. Predicting the field establishment of perennial grass feedstocks: progress made and the challenges ahead. Biofuels 3, 653-656 (2012).

47 Mitchell RB, Vogel KP, Schmer M. Switchgrass (Panicum virgatum) for biofuel production. Sustainable Ag Energy Community of Practice, eXtension (2012). http://extension.org/pages/Switchgrass_for_ Biofuel_Production

48 National Safety Council. 2013. Injury Facts: 2012-2013 Edition. Chicago.

49 NRCS. National Resources Inventory. USDA Natural Resources Conservation Service (2009). http://www.nrcs.usda.gov/technical/ NRI/

50 NRCS.Revised Universal Soil Loss Equation, Version 2 (RUSLE2) (2014).

51 NRCS. Soil Taxonomy: A Basic System of Soil Classification for Making and Interpreting Soil Surveys, $2^{\text {nd }}$ Edition. USDA Natural Resources Conservation Service. Agriculture Handbook Number 436, United States Department of Agriculture, WashingtonDC (1999).

52 Nusser SM, Goebel JJ. The national resources inventory: a long-term multi-resource monitoring programme. Environ. Ecol. Stat. 4, 181-204 (1997).

53 Paine LK, Peterson TL, Undersander DJ et al. Some ecological and socio-economic considerations for biomass energy crop production. Biomass Bioenergy 10, 231-242 (1996).

54 Pan X, Kadla JF, Ehara K, Gilkes, N, Saddler JN. Organosolv ethanol lignin from hybrid poplar as a radical scavenger: relationship between lignin structure, extraction conditions, and antioxidant activity. J. Agric. Food Chem. 54, 5806-5813 (2006).

55 Perrin RK, Vogel KP, Schmer MR, Mitchell RB. Farm-scale production cost of switchgrass for biomass. Bioenergy Res. 1, 91-97 (2008).

56 Pollard AS, Rover MR, Brown RC. Characterization of bio-oil recovered as stage fractions with unique chemical and physical characteristics. J. Anal. Appl. Pyrolysis 93, 129-138 (2012).

57 Sanderson MA, Adler PR, Boateng AA, Casler MD, Sarath G. Switchgrass as a biofuels feedstock in the USA. Can. J. Plant Sci. 86, 1315-1325 (2007).

58 Sanderson MA, Schmer M, Owens V, Keyser P, Elbersen W. Crop management of switchgrass. In: Switchgrass, A Valuable Biomass Crop for Energy. Monti A (Ed). Springer, London, UK, 87-112 (2012).

59 Sanderson MA, Reed R, McLaughlin S et al. Switchgrass as a sustainable bioenergy crop. Bioresour. Technol. 56, 83-93 (1996).

60 Sanderson MA, Egg RP, Wiselogel AE. Biomass losses during harvest and storage of switchgrass. Biomass Bioenergy 12, 107-114 (1997).

61 Sarath G, Dien B, Saathoff AJ, Vogel KP, Mitchell RB, Chen H. Ethanol yields and cell wall properties in divergently bred switchgrass genotypes. Bioresource Tech. 102, 9579-9585 (2011).

62 Secchi SP, Gassman M, Jha L, Kurkalova JL, Kling C. The water quality effects of corn expansion in the Midwest, Ecol. Appl. 21, 1068-1084 (2011).

63 Secchi, SM, Jha H, Feng P, Gassman PW, Kurkalova L, Kling C. Upper Mississippi River Basin modeling system Part 3: conservation practice scenario results. In: Coastal Hydrology and Processes. Singh V, Xu Y. (Eds). Water Resource Publications, Colorado, USA (2006).

64 Shinners KJ, Friede JC. Energy requirements for at-harvest or on-farm size-reduction of biomass. ASABE Paper No. 131591983. St. Joseph, MI (2013). 
65 Shinners KJ, Friede JC. Improving the drying rate of switchgrass. ASABE Paper No. 131591968. St. Joseph, MI (2013).

66 Shinners KJ, Boettcher GC, Muck RE, Weimer PJ, Casler MD. Harvest and storage of two perennial grasses as biomass feedstocks. Trans. ASABE 53, 359-370 (2010).

67 Shinners KJ, Friede JC, Kraus TJ, Anstey D. Improving bale handling logistics by strategic bale placement. ASABE Paper No. 131591987. St. Joseph, MI (2013).

68 Smith DR, Bucholtz D, Brouder S, Volenec J, Turco R, Ejeta G. Greenhouse gas emissions from traditional and biofuel cropping systems. Proceedings of the ASA-CSSA-SSSA Annual Meeting. San Antonio, TX, USA, 16-19 October 2011.

69 Spokas KA, Cantrell KB, Novak JM et al. Biochar: a synthesis of its agronomic impact beyond carbon sequestration. J. Environ. Qual. 41, 973-989 (2012).

70 Steinbeiss S, Gleixner G, Antonietti M. Effect of biochar amendment on soil carbon balance and soil microbial activity. Soil Biol. Biochem. 41, 1301-1310 (2009).

71 Steiner C, Wenceslau G, Lehmann T-J et al. Long term effects of manure, charcoal and mineral fertilization on crop production and fertility on a highly weathered Central Amazonian upland soil. Plant Soil 291, 275-290 (2007). doi:10.1007/s11104-0079193

72 Tallis H, Polasky S. Mapping and valuing ecosystem services as an approach for conservation and natural-resource management. The year in ecology and conservation biology. Ann. N.Y. Acad. Sci. 1162, 265-283 (2009).

73 Thomason WE, Raun WR, Johnson V et al. Switchgrass response to harvest frequency and time and rate of applied nitrogen. J. Plant Nutr. 27, 1199-1226 (2004).

74 Trybula E, Burks JL, Raj C, Chaubey I, Brouder SM, Volenec JJ. Parameterization of perennial bioenergy feedstock grasses in the SWAT model: using field-scale data to improve watershed-scale analysis. (submitted 2014)

75 Trybula E, Chaubey I, Frankenberger J, Brouder SM, Volenec JJ. Quantifying ecohydrologic impacts of perennial rhizomatous grasses on tile discharge, a plot level comparison of continuous corn, mixed prairie, upland switchgrass, and Miscanthus x giganteus. Inter. Meeting of the Amer. Soc. Agron.-Crop Sci. Soc. of Amer.-Soil Sci. Soc. of Amer. Cincinnati, OH, USA, 21-24October 2012. (Abstract 297-9).

76 Vogel KP, Burson BL. Breeding and genetics In: Warm-Season (C4) Grasses. Moser LE, Burson BL, Sollenberger LE (Eds). ASACSSA-SSSA, Madison, WI, USA, 51-94 (2004).

77 Vogel KP, Mitchell RB. Heterosis in switchgrass: biomass yield in swards. Crop Sci. 48, 2159-2164 (2008).

78 Vogel, KP, Mitchell RB, Casler M, Sarath G. Registration of Liberty switchgrass. J. Plant Registrations 8, 242-247 (2014). doi:10.3198/ jpr2013.12.0076crc.

79 Vogel KP, Pedersen JF. Breeding systems for cross-pollinated perennial grasses. Plant Breed Rev. 11, 251-274 (1993).
80 Vogel KP. Switchgrass. In: Warm-Season (C4) Grasses. Moser LE, Sollenberger L, Burson B (Eds). ASA-CSSA-SSSA Monograph, Madison, WI, USA, 561-588 (2004).

81 Vogel KP, Sarath G, Saathoff AJ, Mitchell RB. Switchgrass. In: Energy Crops. Halford NG, Karp A. (Eds). Royal Society of Chemistry, London, UK. (2011).

82 Vogel KP, Brejda JJ, Walters DT, Buxton DR. Switchgrass biomass production in the Midwest USA: harvest and nitrogen management. Agron. J. 94, 413-420 (2002).

83 Vogel, KP, Schmer MR, Mitchell RB. Plant adaptation regions: ecological and climatic classification of plant materials. Rangeland Ecol. Manage. 58, 315-319 (2005).

84 Wiebe, K. Linking Land Quality, Agricultural Productivity, and Food Security. Resource Economics Division, Economic Research Service, US Department of Agriculture. Agricultural Economic Report No. 823, Washington DC (2003).

85 Woodson P, Volenec JJ, Brouder SM. Field-scale potassium and phosphorus fluxes in the bioenergy crop switchgrass: theoretical energy yields and management implications. J. Plant Nutr. Soil Sci. 176, 387-399 (2013).

86 Wright MM, Brown RC, Boateng AA. Distributed processing of biomass to bio-oil for subsequent production of Fischer-Tropsch liquids. Biofuels, Bioprod. Biorefin. 2, 229-238 (2008).

87 Zhou J, Song F, Swinton S. Switching to perennial energy crops under uncertainty and costly irreversibility. Am. J. Agric. Econ. 93, 768-783 (2011). 